\title{
Calcifying Aponeurotic Fibroma
}

National Cancer Institute

\section{Source}

National Cancer Institute. Calcifying Aponeurotic Fibroma. NCI Thesaurus. Code C4818.

A rare slow-growing benign neoplasm arising from the soft tissues in children. It is a poorly circumscribed tumor characterized by the presence of chondrocyte-like cells, nodular calcification, nuclear palisading, and in some cases osteoclastic giant cells. 